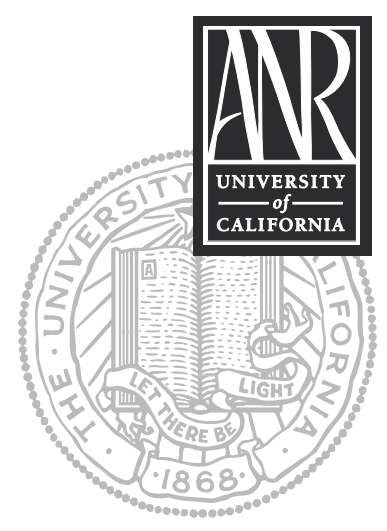

UNIVERSITY OF CALIFORNIA

Division of Agriculture and Natural Resources http://anrcatalog.ucdavis.edu

\title{
Ozone Applications for Postharvest Disinfection of Edible Horticultural Crops
}

TREVOR V. SUSLOW, Extension Postharvest Specialist, Department of Vegetable Crops, University of California, Davis

Although much of the stimulation of interest in ozone $\left(\mathrm{O}_{3}\right)$ as a water and cold storage disinfectant and general treatment for extending shelf life has been based on empirical information and testimonials, an increasing body of recent scientific literature has better defined the benefits and limitations of gaseous and aqueous ozonation in postharvest applications on edible horticultural crops.

Three key events have stimulated an even higher level of interest in postharvest applications of ozone for decay control and as a sanitizer against human pathogens:

- broader consumer demand for enhanced availability of fresh produce of the highest standard in quality, nutritional value, and safety

- concern, borne of media and public attention, about known or potential human health and negative environmental impacts of chlorinated disinfectant by-products

- regulatory acceptance that ozone has been affirmed to qualify for Generally Recognized as Safe (GRAS) status as a food-processing aide, and the listing of ozone as compliant (no restrictions or concerns) with EPA Disinfection by Products Rule

This publication provides an introductory overview of the properties, applications, known efficacy, and worker exposure and safety consideration of applying ozone in the postharvest environment.

\section{REGULATORY STATUS}

In a lengthy self-affirmation and extensive petition process, an expert advisory panel asserted the determination that ozone qualified for listing as a GRAS material. On June 26, 2001, the U.S. Food and Drug Administration (FDA) released an official acceptance (by abandoning a challenge of this assertion) of this determination (21 CFR Part 173.368) on the permissible use of ozone as an antimicrobial agent for the treatment, storage, and processing of foods in gas and aqueous phases in direct contact with foods, including raw and minimally processed fruits and vegetables.

Ozone-based treatment of fresh vegetables and fruits had been used in the postharvest handling industry for decades. However, relatively few produce handlers and processors have used ozone for water disinfection, surface sanitation, cold room air treatment, and other postharvest applications such as final rinses of whole, trimmedin-the-field, peeled, or minimally processed produce. Until GRAS status was affirmed, the legality of ozone contact with food was always an area of regulatory uncertainty.

By regulation, ozonation treatment of fresh produce and all related handling and applications must be conducted in a manner consistent with Good Manufacturing Practices (GMP). Specifically, ozone has been approved for use under GMP, meaning "exposure of foods to sufficient ozone (concentrations and times of exposure) to accomplish its intended purpose." This translates to the minimum exposure of fruits and vegetables to that dose of ozone necessary to provide the target antimicrobial benefits on specific edible horticultural commodities. Unlike other common water 
disinfectants and produce surface sanitizers (e.g., chlorine $(\mathrm{Cl})$ gas, calcium hypochlorite $\left(\mathrm{Ca}(\mathrm{OCl})_{2}\right.$, sodium hypochlorite $(\mathrm{NaOCl})$, peroxyacetic acid), no postharvest uses of ozone in contact with produce are currently registered by the U.S. Environmental Protection Agency (EPA) or the California Department of Pesticide Regulation (DPR). Rather, due to the onsite generation of ozone, each ozone generator unit is required to have an EPA establishment number and a device registration number. Registration is conducted under the approved testing protocols conducted by NSF International: Nonfood Compounds Registration Program (see http://www.nsf.org/usda).

\section{PROPERTIES OF OZONE}

Ozone is a very pungent, naturally occurring gas with strong (highly reactive) oxidizing properties. Ozone has a very long history of safe use in disinfection of municipal water, process water, bottled drinking water, and swimming pools. More recent applications include treatment of wastewater, dairy and swine effluent, cooling towers, hospital water systems and equipment, aquariums and aquaculture, water theme parks, and public and in-home spas.

In clean, potable water free of organic debris and soil particulates, ozone is a highly effective sanitizer at concentrations of 0.5 to $2 \mathrm{ppm}(1 \mathrm{mg} / \mathrm{L}=1 \mathrm{ppm})$. Ozone is almost insoluble in water $\left(0.00003 \mathrm{~g} / 100 \mathrm{~mL}\right.$ at $\left.20^{\circ} \mathrm{C}\left[68^{\circ} \mathrm{F}\right]\right)$, and effective dispersal is essential for antimicrobial activity. Ozone's disinfectant activity is only marginally affected at a water $\mathrm{pH}$ from 6 to 8.5. Ozone is highly corrosive to equipment and is lethal to humans with prolonged exposure at concentrations above $4 \mathrm{ppm}$. Ozone is readily detectable by human smell at 0.01 to $0.04 \mathrm{ppm}$. Federal Occupational Safety and Health Adminisration (OSHA) limits of exposure specify a $0.1 \mathrm{ppm}$ threshold for continuous exposure during an 8-hour period and $0.3 \mathrm{ppm}$ for a 15-minute period. At $1 \mathrm{ppm}$ ozone has a pungent disagreeable odor and is irritating to the eyes and throat.

For high-dose applications necessary to disinfect recirculating postharvest water used in an open-flume or for manifold-style spray-bars, off-gas containment and destruction (conversion back to oxygen) is essential. Each system design should be carefully evaluated to protect worker comfort and safety. Current experience would not forecast a serious problem for line workers at general injection doses.

Ozone is also highly unstable in water and decomposes to oxygen in a very short time. Less than half the ozone activity remains after 20 minutes in pure water and the activity may only have a residual of 2 to 3 minutes in more complex, potable water. In postharvest packing water or fresh-cut processing water with suspended soil and organic matter, the half-life of ozone activity may be less than 1 minute. Lower water temperatures extend the half-life of ozone. Specific water quality constituents, increasing alkalinity, soluble iron and manganese content, hydrogen sulfide, humic acids, and soluble organic compounds delay the buildup of detectable ozone residuals in the water and reduce the apparent half-life of ozone.

As a consequence of the low stability, maintaining effective concentrations of dissolved ozone for microbial disinfection by using remote ozone generation and injection into a centralized water system, as is done with chlorine and chlorine dioxide $\left(\mathrm{ClO}_{2}\right)$, has proved difficult or impractical. This low stability, however, is one of the perceived benefits of ozone as a disinfectant. When ozone breaks down it forms oxygen (see below), and it has not been identified as creating undesirable disinfection by-products. With increased use in postharvest handling of fresh vegetables and fruits the difficulties of using remote ozone generation and injection will very likely be overcome. In some applications, a reduced amount of hypochlorite or other more stable disinfectant (lower than if used as the sole oxidizing agent) is added to water to provide a residual effect downstream of the primary ozone injection. Common residual water treatment concentrations range from 0.5 to $2 \mathrm{ppm}$ free chlorine. For more infor- 
mation on postharvest chlorination, see Postharvest Chlorination: Basic Properties and Key Points for Effective Sanitation (ANR Publication 8003) and Water Disinfection: A Practical Approach to Calculating Dose Values for Preharvest and Postharvest Applications (ANR Publication 7256).

\section{How Is Ozone Formed?}

Ozone is formed by a high-energy input that splits the $\mathrm{O}_{2}$ (oxygen) molecule. Single oxygen $(\mathrm{O})$ molecules rapidly combine with available $\mathrm{O}_{2}$ to form the very reactive ozone $\left(\mathrm{O}_{3}\right)$.

In nature, ozone is formed by ultraviolet (UV) irradiation $(185 \mathrm{~nm}$ ) from the sun and also during lightning discharge. Ozone may also be formed by commonly used equipment such as photocopiers, laser printers, and other electrical devices. Commercially, UV-based generators pass ambient air $\left(20 \% \mathrm{O}_{2}\right)$ or oxygen-enriched air across a UV light source, typically less than $210 \mathrm{~nm}$. These systems have a lower cost but also have a more limited output than corona discharge systems. Corona discharge generators pass dry, $\mathrm{O}_{2}$-enriched air or highly purified $\mathrm{O}_{2}$ across a high electric voltage $(>5,000 \mathrm{~V})$, or corona, similar to a spark plug.

Gaseous ozone may be pumped into the air space of a properly constructed postharvest storage facility or storage unit. For aqueous applications, ozone is pulled into a water stream under the negative pressure created by a Venturi injection system. Bubbling the generated ozone into an assimilation water tower through an air stone is used in some situations, but it is deemed far less efficient. Excess ozone not dispersed in water must be captured and destroyed to prevent corrosion and personal injury. One method of destruction is by UV light at a longer wavelength $(254 \mathrm{~nm})$ combined with the use of a catalytic agent or granular activated charcoal.

\section{MEASURING AND MONITORING OZONE}

Effective but safe concentrations of ozone are difficult to maintain in typical postharvest applications because automated detection systems have not been highly reliable in complex (dissolved or suspended inorganic and organic constituents) process water. Due to this uncertainty of reported ozone injection values, past research is often difficult to evaluate and reproduce with reported concentrations of delivered ozone in an experimental or commercial system. Newer electrode probes that measure oxidation-reduction potential (ORP) of the water and colorimetric kits based on indigo blue (indigo trisulfonate) are being used to monitor ozone concentrations more accurately, but problems in practical application still exist.

Dissolved ozone monitors, though more accurate and more predictive of the residual ozone in process water, are too expensive for most practical situations. Currently, ORP sensors are used to measure the disinfection potential of the treated water and monitor ozone generation demand in a continuous feedback system. These sensors are most useful in monitoring the generator output immediately downstream from the injector. The relation between the mass of generated ozone dissolved in water and ORP in millivolts $(\mathrm{mV})$ is not a constant linear relationship. ORP does, nonetheless, reasonably reflect both the buildup of an ozone residual and the antimicrobial oxidative status of the water. Other available monitoring test kits, based on DPD (N,N-Diethyl-1,4phenylenediamnie sulfate), depend on oxidative dye quenching. These are the same substrates used in many rapid chlorine titration kits and are subject to interference by any other oxidative species, for instance, by hypochlorous acid ( $\mathrm{HOCl})$ or chlorine dioxide). 


\section{USING OZONE}

\section{How Does Water Quality Impact Effectiveness?}

Dissolved and suspended organic and inorganic substances react quickly with ozone and interfere with the desired antimicrobial action. Similar to chlorine, water quality has an important impact on ozone demand and stability in water. In particular, dissolved iron $(\mathrm{Fe})$, manganese $(\mathrm{Mn})$, copper $(\mathrm{Cu})$, nickel $(\mathrm{Ni})$, hydrogen sulfide $\left(\mathrm{H}_{2} \mathrm{~S}\right)$, and ammonia $\left(\mathrm{NH}_{3}\right)$ increase the ozone concentration and contact time needed for maximum lethality to microorganisms. Complexes of suspended organics and inorganics have been shown to provide a protective effect for microbes against the action of ozone. High suspended-solids and insufficient contact time in flumes or drench tanks are often cited as the responsible factor for lower-than-expected reductions in viable microbial counts from treated water, often no more than a tenfold ( $1 \log )$ decrease. For this reason, an appropriate series of screens and filtering of source water may be needed. Filtration is essential for any use of ozone in recirculated water systems such as flumes and hydrocoolers. With adequately filtered systems, a 3 to $4 \log$ (up to 99.99\%) reduction in microbial load may be expected with short treatment exposure, and as high as $5 \log$ reductions (99.99\% kill) have been reported in pilot trials.

Well water generally has lower organic and higher inorganic loads than surface water. Hydrogen sulfide may be a problem in water from deep wells, and ozone can be used to deodorize the water. Recirculated process water has a higher microbial load, higher suspended organic solids, and, potentially, higher pesticide residues and other organic chemicals than nonrecirculated water. Because of ozone's reactivity with organics, its use may actually assist filtration devices in clarifying recirculating process or cooling water. Ozone treatment oxidizes a wide array of organic contaminants and improves the efficiency of water clarification by flocculation and biological degradation.

\section{How Is Ozone Applied to Water?}

The ozone generator supply line connects to the process water supply or return line at a Venturi-type injection disperser unit. Adequate mixing and sensitive process monitoring are essential for uniform treatment with the low concentrations of ozone applied to water for most postharvest uses. Chilling the water and lowering the $\mathrm{pH}$ increases the solubility. Typical ozone use rates for disinfection of postharvest water are 2 to 3 ppm. Maximizing ozone output increases mass transfer efficiency; modern injection systems can easily achieve $6 \mathrm{ppm}$ or greater. Protection of equipment and worker safety must always be paramount in system design and operations.

\section{How Does Ozone Compare to Chlorine?}

Ozone is reported to have 1.5 times the oxidizing potential of chlorine and 3,000 times the potential of hypochlorous acid. Contact times for antimicrobial action are typically 4 to 5 times less than those for chlorine. Ozone rapidly attacks bacterial cell walls and is more effective than chlorine against the thick-walled spores of plant pathogens and animal parasites, at practical and safe concentrations.

Compared with the potential negative effects of residues and organic reaction products formed with chlorine applications, ozone does not form deleterious chlorinated hydrocarbons, trihalomethanes (such as chloroform), and other chlorinated disinfection by-products. Oxidized products with potentially deleterious properties may form by oxidation (i.e., an oxidized bromide ion may further react with water constituents to form a type of trihalomethane or mildly toxic bromate ion) or by the breakdown of complex organic materials to simpler forms. Concern has been raised for the unknown consequences of pesticide oxidation in water or on produce. We are unaware of any reported health or environmental risk from the discharge of ozonated wash, cooling, or produce processing water. More typically, significant savings in 
wastewater disposal charges and a lower overall net cost of disinfection are ascribed to switching from chlorine-based systems to ozone applications. Partial oxidation of organic contaminants or constituents of wastewater by ozonation has been shown to accelerate biological conversion. Presumably, ozonation of discharge water makes these recalcitrant nutrient sources more available. Of course, in some environmental water systems into which process water may be released, this elevated microbial growth may be undesirable, and subsequent treatments or other water quality protection steps may be needed.

\section{Has Ozone Been Tried for Other Postharvest Uses?}

Ozone has been evaluated for postharvest disease control and other storage uses for many years. Some commercial use has occurred with commodities such as apples, cherries, carrots, garlic, kiwi, onions, peaches, plums, potatoes, and table grapes. There is increasing interest and a great deal of empirical activity in the evaluation of ozone for a diversity of water treatment and air treatment (fumigation) uses in postharvest quality management. Examples include ethylene degradation within a confined reactor, odor elimination for mixed storage, disinfection of humidification systems and cold storage room surfaces (including retail supermarkets), fungal spore elimination in storage room aerosols, and treatment of superficial mold after long-distance shipping of onions. At doses required for effective disease control, phytotoxicity (localized product damage) in ozonated air have been experienced for table grapes (fruit and rachis damage), carrots (bleaching), and tomatoes (calyx and vine/cluster desiccation and browning).

Introducing gaseous ozone into postharvest storage facilities or refrigerated shipping and temporary storage containers is reported to be optimal at cooler temperatures and higher relative humidity ( 85 to $<95 \%$ ). The most reproducible benefits to storage operations are in the substantial reduction of fungal spore production on the surface of infected produce and the exclusion of secondary spread from infected produce to adjacent produce (various fruits and tubers have been the subject of most evaluations). In laboratory inoculation studies, control of surface inoculated pathogens can be highly effective due to uniform exposure and controlled conditions. The application of gaseous ozone to commercial storage rooms or containers has not been reliable in reducing net decay from natural infections acquired in the field or during harvest handling. These infections are generally within or beneath the plant surface. Ozone, as with any currently used disinfectant, does not penetrate natural openings or wounds efficiently; it also tends to react rapidly with exposed oxidizable plant materials rather than with pathogen cell walls. In addition, uniform contact exposure is not practical or achievable in packed cartons or bins. Product-to-product and product-to-packing material contact prevents ozone contact with the pathogen, even if contamination is superficial. Greater success in wound penetration by chlorine dioxide, in comparison to gaseous ozone, has been reported, but substantiation in practice remains to be evaluated. A final obstacle to fully effective performance of gaseous ozone applications in postharvest storage facilities is the barriers inherent in the packages or containers. This is largely a function of the degree of venting possible without compromising stacking strength or, in the case of consumer packaging units, excessive water loss. Tests have shown that packed units with high vent area, such as returnable plastic containers (RPC), have a higher degree of suppression of fungal growth on product surfaces than units with more restrictive air-exchange openings.

In general, ozone treatments in postharvest storage have the greatest economic benefit when stored produce will be sorted prior to shipment or repacked following distribution and short-term storage to remove decayed produce. When designing a treatment room, note that the presence of wood surfaces, urethane insulation, fiber- 
board, and other corrugated materials in the storage facility will create an additional demand on ozone application that may reduce the effective delivered dose.

The benefits of ozone treatment in cold storage rooms or facilities may be direct and indirect. Ozone destruction of ethylene in air filtration systems has been linked to extended storage life of diverse ethylene-sensitive commodities. Injection of gaseous ozone, at nonhazardous levels, into the common air of a cold storage room has not been as effective in destroying ethylene and reducing odor as forced circulation (high air exchange) of the conditioned air through an ozone reaction chamber. Simply, at low concentrations of ozone, random encounters with ethylene or objectionable odor volatiles is too slow a process. It is more efficient to bring the air into direct contact with ozone in a ceiling-mounted unit. In addition, ozone treatment has been reported to induce natural plant defense response compounds thought to be involved in postharvest decay resistance. However, excessive exposure to ozone may injure plant tissue and effectively reduce storage or sensory life.

\section{Has Ozone Been Evaluated for Use in Food Safety?}

Ozone applications for decay and spoilage control have been closely paralleled, more recently, by investigations of human pathogen disinfection in water and on equipment, packing surfaces, returnable plastic containers and bins, and transport vehicles. As with postharvest plant pathogens, eliminating bacterial pathogens such as Salmonella spp., E. coli O157:H7, and Shigella spp. is relatively easy in 'clean' water and becomes increasingly more difficult in water of complex quality, on the surface of produce, or with more tolerant spore-forming or parasitic pathogens. Gaseous ozone treatment of cold rooms has been reported to be effective in significantly reducing Listeria monocytogenes.

Additional research is needed to define the potential and limits of the effective use of ozone for postharvest treatments for the quality and safety of whole and minimally processed vegetables and fruits.

Currently, ozone is not registered by the California DPR as a postharvest treatment for direct contact with produce. The recent determination by the FDA supporting petition for GRAS classification of ozone as a disinfectant for foods has opened the door for the produce industry to explore its many potential benefits, when applied in a manner consistent with good manufacturing practices.

\section{B IBLIOGRAPHY}

Barth, M. M., C. Zhou, J. Mercier, and F. A. Payne. 1995. Ozone storage effects on anthocyanin content and fungal growth in blackberries. Journal of Food Science 60:1286-1288.

Beltran, F. J., J. M. Encinar, and J. F. Gonzalez. 1997. Industrial wastewater advanced oxidation: Part 2. Ozone combined with hydrogen peroxide or UV radiation. Water Research 31:2415-2428.

Botzenhart, K., G. M. Tarcson, and M. Ostruschka. 1993. Inactivation of bacteria and coliphages by ozone and chlorine dioxide in a continuous flow reactor. Water Science and Technology 27:363-370.

Bullock, G. L., S. T. Summerfelt, A. C. Noble, A. L. Weber, M. D. Durant, and J. A. Hankins. 1997. Ozonation of a recirculating rainbow trout culture system: I. Effects on bacterial gill disease and heterotrophic bacteria. Aquaculture 158:43-55.

Graham, D. M. 1997. Use of ozone for food-processing. Food Technology. 51: 72-75.

Han, Y., J. Floros, R. Linton, S. Nielsen, and P. Nelson. 2002. Response surface modeling for the inactivation of Escherichia coli O157:H7 on green peppers (Capsicum annum) by ozone gas treatment. Journal of Food Microbiology and Safety. 67:1188-1199. 
Hunt, N. K., and B. J. Marinas. 1997. Kinetics of Escherichia coli inactivation with ozone. Water Research 31:1355-1362.

Joret, J. C., V. Mennecart C. Robert, B. Compagnon, and P. Cervantes. 1997. Inactivation of indigenous bacteria in water by ozone and chlorine. Water Science and Technology 35:8.

Khadre, M., and A. Yousef. 2001. Sporicidal action of ozone and hydrogen peroxide: A comparative study. International Journal of Food Microbiology 71:131-138.

Kim, J., A. Yousef, and S. Dave. 1999. Application of ozone for enhancing the microbiological safety and quality of foods: A Review. Journal of Food Protection 62:1071-1087.

Liew, C. L., and R. K. Prange. 1994. Effect of ozone and storage temperature on postharvest diseases and physiology of carrots (Daucus carota L.). Journal of the American Society for Horticultural Science 119:563-567.

Palou, L., C. Crisosto, J. Smilanick, J. Adaskaveg, and J. Zoffoli. 2002. Effects of continuous ozone exposure on decay development and physiological responses of peaches and table grapes in cold storage. Postharvest Biology and Technology 24:39-48.

Palou, L., J. Smilanick, C. Crisosto, M. Mansour, and P. Plaza. 2003. Ozone gas penetration and control of the sporulation of Penicillium digitatum and Penicillium italicum within commercial packages of oranges during cold storage. Crop Protection 22:1131-1134.

Richardson, S. D., et al. 1998. Chemical by-products of chlorine and alternative disinfectants. Food Technology 52:58-61.

Sarig, P., T. Zahavi, Y. Zutkhi, S. Yannai, N. Lisker, and R. Ben-Arie. 1996. Ozone for control of post-harvest decay of table grapes caused by Rhizopus stolonifer. Physiological and Molecular Plant Pathology 48:403-415.

Watkins, B. D., S. M. Hengemuehle, H. L. Person, M. T. Yokoyama, and S. J. Masten. 1997. Ozonation of swine manure wastes to control odors and reduce the concentrations of pathogens and toxic fermentation metabolites. Ozone Science and Engineering 19:425-437. 


\section{FOR FURTHER INFORMATION}

You'll find more information on postharvest ozone use in the following ANR Communication Services publications:

Postharvest Chlorination: Basic Properties and Key Points for Effective Sanitation, Publication 8003, 1997 available for free downloading at http://ucgaps.ucdavis.edu and http://anrcatalog.ucdavis.edu/pdf/8003.pdf.

Postharvest Technology of Horticultural Crops, Second Edition, Publication 3311, 2002.

Water Disinfection: A Practical Approach to Calculating Dose Values for Preharvest and Postharvest Applications, Publication 7256, 2001, available for free downloading at http://anrcatalog.ucdavis.edu/pdf/7256.pdf

To order or obtain these publications and other products, visit the ANR Communication Services online catalog at http://anrcatalog.ucdavis.edu. You can also place orders by mail, phone, or FAX, or request a printed catalog of our products from:

University of California

Agriculture and Natural Resources

Communication Services

6701 San Pablo Avenue, 2nd Floor

Oakland, California 94608-1239

Telephone: (800) 994-8849 or (510) 642-2431; FAX: (510) 643-5470

E-mail inquiries: danrcs@ucdavis.edu

An electronic version of this publication is available on the ANR Communication Services Web site at http://anrcatalog.ucdavis.edu.

\section{Publication 8133}

(C) 2004 by the Regents of the University of California, Division of Agriculture and Natural Resources. All rights reserved.

The University of California prohibits discrimination against or harassment of any person employed by or seeking employment with the University on the basis of race, color, national origin, religion, sex, physical or mental disability, medical condition (cancer-related or genetic characteristics), ancestry, marital status, age, sexual orientation, citizenship, or status as a covered veteran (special disabled veteran, Vietnam-era veteran or any other veteran who served on active duty during a war or in a campaign or expedition for which a campaign badge has been authorized). University Policy is intended to be consistent with the provisions of applicable State and Federal laws.

Inquiries regarding the University's nondiscrimination policies may be directed to the Affirmative Action/Staff Personnel Services Director, University of California, Agriculture and Natural Resources, 300 Lakeside Drive, 6th Floor, Oakland, CA 94612-3550 (510) 987-0096. For a free catalog of other publications, call (800) 994-8849. For help downloading this publication, call (530) 754-5112.

pr-5/04-SB/CR

ISBN 978-1-60107-312-9

The information contained in this publication should not be viewed as an authoritative source for current registration status or legal use recommendations of any product. For more information, contact the California Department of Pesticide Regulation Information Center at (916) 324-0399.

This publication has been anonymously peer reviewed for technical accuracy by University of California scientists and other qualified professionals. This review process was managed by the ANR Associate Editor for Vegetable Crops. 